\title{
Therapeutic Effect Of Warm Fragrant Lemongrass Foot Soak Against Changes In The Joint Pain Scale Of Rheumatoid Arthritis Patients
}

\author{
Muhammad Syahwal $^{1 *}$, Aluddin ${ }^{1}$ \\ ${ }^{1}$ Nursing diploma study program, PPNI Kendari nursing academy, \\ Kendari, Indonesia \\ * Corresponding author: \\ Email: awaljhe@gmail.com
}

\begin{abstract}
.
Uric acid is a natural antioxidant produced by the human body, but it can trigger rheumatoid arthritis if the amount exceeds the normal threshold with typical symptoms in the form of pain accompanied by swelling in the joint area, even in advanced conditions there is joint stiffness. Cymbopogon nardus (L.) Rendle or lemongrass is an effective plant to reduce joint pain and swelling. The purpose of this study was to describe the effect of warm lemongrass foot bath therapy on changes in the scale of joint pain in patients with rheumatoid arthritis. This study is a pre-experimental study with one group pre-test and post-test design without a control group, changes after two days of soaking warm lemongrass feet by observing changes in the pain scale of 23 respondents. The Wilcoxon test results showed that there was a change in the pain scale after intervention with a value of $p$ $=0.01$, which means that warm scented lemongrass foot soak affects reducing the pain scale of patients with rheumatoid arthritis. The warm sensation of the foot soaking intervention provides a peripheral vasodilation effect which causes a decrease in joint pain in inflamed tissues, the chemical effect of citronellal compounds is around 32-45\%, geraniol 12-18\%, and citronellol $12-25 \%$ in citronella plants are also proven to play a role in reducing pain. This study concluded that warm lemongrass foot soaking therapy affected the changes in the scale of joint pain in Rheumatoid Arthritis
\end{abstract}

Keywords: Soak Feet, Lemongrass, Rheumathoid Arthritis.

\section{INTRODUCTION}

One of the common inflammatory joint diseases is rheumatoid arthritis, a typical complaint found is pain and swelling of the joints which, if not treated immediately, can cause joint stiffness that hinders activity, this is often experienced by a group of men over 30 years old and postmenopausal women [1], [2]. Uric acid is a natural antioxidant produced by the human body, but it can trigger rheumatoid arthritis if the amount exceeds the normal threshold [3].

It is known that about $57 \%$ of the elderly in the world experience chronic problems in the bone and joint systems, $40 \%$ of which are diagnosed with arthritis, treatment is recommended to use non-pharmacological therapy with the consideration that pharmacological therapy will be given continuously has the potential to cause dependence and disrupt the elderly's organs [4], [5]. Joint pain problems, especially in 
the elderly group, must be treated immediately so that the symptoms do not worsen as the patient ages [6].

Cymbopogon nardus (L.) Randle or better known to the public is lemongrass or red lemongrass which is a plant that contains essential oils that provide a warm and spicy sensation to the body so that it can reduce pain and joint swelling due to vasodilation of blood vessels and blood circulation. resulting in muscle relaxation which results in reduced pain and swelling [7], [8] giving warm therapy is also more effective in reducing pain complaints than other therapies that use cold temperatures [9]. Pain control, especially in the elderly, is directed at a non-pharmacological therapeutic approach because it is considered safer, easier to implement, and utilizes natural ingredients that are available in our environment [10]. The Indonesian people have long used various types of plants as medicine but they have not been fully documented so that research related to the use of plants as a medium for treatment is urgently needed [3], [11].

\section{METHODS}

This research was pre-experimental with one group pre-test and post-test design without a control group, the results of the observation of the pain scale after the intervention of foot soaking using warm water with a mixture of lemongrass for 2 (two) days to obtain conclusions about the effect of this therapy on patients with rheumatoid arthritis [12], [13].

The population of this study was 23 people with rheumatoid arthritis in the Social Home of Tresna Werdha Minaula Kendari. Univariate analysis was carried out on each variable to produce an average, minimum and maximum value distribution for each variable, bivariate analysis began with a normality test using the Mann Withney test, if a normal data distribution description was obtained, a parametric statistical test was performed using the Dependent T-Test. and if the data distribution is not normal, a non-parametric Wilcoxon statistical test is performed [14].

Determination of the research sample by total sampling. Research ethics No. 126 / KEPK-IAKMI / VII / 2020 was obtained from Pengda IAKMI Southeast Sulawesi Province

\section{RESULT AND DISCUSSION}

Table 1.The distribution of characteristics of respondents with rheumatoid

\begin{tabular}{lccc}
\multicolumn{4}{c}{ arthritis $(\mathrm{N}=23)$} \\
\hline \multicolumn{1}{c}{ Characteristics } & frequency & Percentage (\%) \\
\hline Gender: & 9 & 39,1 \\
Male & 14 & 60,9 \\
Female & 13 & 56,52 \\
\hline Respondent age: &
\end{tabular}




\begin{tabular}{lcc}
$75-90$ year (old) & 10 & 43,48 \\
\hline long suffered: & 7 & \\
3 - 5 year & 15 & 30,43 \\
6 - 8 year & 1 & 65,22 \\
$9-10$ year & 4,35 \\
\hline
\end{tabular}

Based on table 1, it is known that the research respondents were dominated by women as many as 14 people $(60.9 \%)$, the highest age frequency of respondents was 60-74 years (elderly old) as many as 13 people $(56.52 \%)$ and the age of $75-90$ years (old). ) as many as 10 people (43.48\%) while the highest frequency in terms of duration of suffering from rheumatoid arthritis was $6-8$ years as many as 15 people $(65.2 \%)$ and the lowest frequency was $9-10$ years as many as 1 people $(4.35 \%)$.

Table 2. Effect of warm scented lemongrass foot soak on pain scale for patients with rheumatoid arthritis $(\mathrm{N}=23)$

\begin{tabular}{ccccccccc}
\hline \multirow{2}{*}{ Measurement } & \multicolumn{7}{c}{ Pain scale (NRS) } & \multirow{2}{*}{$Z$} \\
\cline { 2 - 8 } & mild & $\%$ & moderate & $\%$ & severe & $\%$ & & \\
\hline Pre test & 0 & 0 & 8 & 34,78 & 15 & 65,22 & \multirow{2}{*}{0,01} & \multirow{2}{*}{-4.021} \\
\hline Post test & 9 & 39,13 & 14 & 60,87 & 0 & 0 & \\
\hline
\end{tabular}

In table 2. Shows changes in the pain scale before the warm lemongrass foot soak therapy, there are 8 respondents $(34.78 \%)$ with moderate pain scale, 15 respondents $(65.22 \%)$ with severe pain scale, then the results of measuring pain after therapy are known 9 respondents $(39.13 \%)$ respondents with a light scale, 14 respondents $(60.86 \%)$ on a moderate scale and no more pain on a heavy scale. Wilcoxon test results to obtain a value of $\mathrm{p}=0.01$ means that warm lemongrass foot soak therapy affects reducing the pain scale of patients with rheumatoid arthritis.

Pain is described as an unpleasant experience that is often experienced by individuals with different intensity, location, quality, and duration so that it can lead to different perceptions of pain in each individual who feels it [15]. In terms of pain response based on sex, it is known that in general, the male group did not express more pain than the female group [16]. Furthermore, in terms of age, it is known that rheumatoid arthritis is one of the disorders of the metabolic system with an age range of patients over 40 years old, this is due to the body's physiological conditions which begin to experience a decline in function and disorders of the metabolic system.

The therapeutic effect of foot soaking using a mixture of lemongrass in the form of a change in the pain scale after two interventions, according to the researchers, is caused by a warm sensation during foot soak therapy that gives a signal to the hypothalamus through the spinal cord, this causes an increase in blood flow to each tissue, especially at the pain site peripheral vasodilation effect resulting in decreased joint pain in inflamed tissues, another factor is the chemical effect contained in citronella such as $32-45 \%$ citronellal compounds, $12-18 \%$ geraniol and $12-25 \%$ citronellol based on literature studies as well. proven to reduce pain [17], [18]. 
It is known that several respondents had previously received foot soaking therapy using either warm water or using other plants but the warm sensation that was felt this time was more absorbed into the skin. The results of a similar study state that nonpharmacological measures using lemongrass can reduce rheumatoid arthritis pain in the elderly and this method has a lower risk [7]. Research also concluded that there was a decrease in the scale of pain in the elderly with rheumatoid arthritis after being given therapy using warm lemongrass [19].

Excess uric acid levels in the blood will form sharp crystals and collect in the joints especially the peripheral joints so that friction between the joints causes increased pain, swelling, redness, and stiffness [20]. This therapeutic effect also causes improved blood circulation so that the crystallization of uric acid which is concentrated in the joints can dissolve back into the blood and be excreted in the urine.

Complaints of joint pain that are felt again in patients with rheumatoid arthritis illustrate that the symptoms of this disease are recurring so that foot soaking therapy is only one form of companion therapy, sufferers must also pay attention to diet and light physical activity, this is based on the results of interviews which are also It was conducted when the research was known that mild pain was found in respondents who often did physical activity such as morning walks, visiting close neighbors, regular exercise every day and consuming a variety of foods compared to elderly people who were passive and often consumed foods with purine content such as spinach and chicken

\section{CONCLUSION}

This study concludes that warm scented lemongrass foot soak affects reducing the scale of joint pain in patients with rheumatoid arthritis $(p=0.01)$.

It is suggested to the next researchers to do foot soaking therapy using water media with different temperatures to find out more about the effectiveness of citronella plants to changes in the pain scale, the age of the respondents is not focused on the elderly and the research sample is in larger numbers.

\section{ACKNOWLEDGMENTS}

The authors are grateful to Deputy for Research and Development Strengthening Ministry of Research and Technology / National Research and Innovation agency of the Republic of Indonesia for the 2019 Lecturer Research Grant program, Head of Region IX Sulawesi Higher Education Service Institute, Head of Research and Development Agency for Southeast Sulawesi Province, Commission on Ethics for Regional Administrators of the Association of Indonesian Public Health Experts in Southeast Sulawesi and also Head of the Tresna Werdha Social Home, Minaula Kendari 


\section{REFERENCES}

[1] Kertia Nyoman, Asam Urat. Yogyakarta: PT Bentang Pustaka, 2009.

[2] N. Kusumawardani, R. Soerachman, A. D. Laksono, L. Indrawati, P. Sari, and A. Paramita, Penelitian Kualitatif di Bidang Kesehatan, vol. 53, no. 9. 2015.

[3] D. Hidayat and G. Hardiansyah, "Studi Keanekaragaman Jenis Tumbuhan Obat di Kawasan IUPHHK PT . Sari Bumi Kusuma Camp Tontang Kabupaten Sintang,” J. Vokasi, vol. 8, pp. 61-68, 2012.

[4] S. U. B. Chairani, "Repository Studi Fenomenologi : Pengalaman Hidup Lansia dengan Osteoarthritis di Wilayah Kerja Puskesmas Kebun Sikolos Padang Panjang Tahun 2015," Universitas Andalas, 2015.

[5] R. Amilia, "Pengaruh Kompres Hangat Terhadap Nyeri Artritis Gout Pada Lanjut Usia Di Kampung Tegalgendu Kecamatan Kotagede Yogyakarta," 2013.

[6] V. L. Brashers, Aplikasi Klinis Patofisiologi: Pemeriksaan dan Manajemen, 2nd ed. Jakarta: EGC, 2007.

[7] M. Andriani, "Pengaruh Kompres Serei Hangat Terhadap Penurunan Intensitas Nyeri Artritis Rheumatoid Pada Lanjut Usia," J. Iptek Terap., vol. 10, no. 1, 2016, doi: 10.22216/jit.2016.v10i1.431.

[8] V. M. D. Anugraheni and A. Wahyuningsih, “Jurnal STIKES," Ef. kompres hangat dalam menurunkan intensitas nyeri dysmenorrhea pada mahasiswi STIKES RS Baptis Kediri, vol. 6, no. 1, pp. 1-10, 2013, [Online]. Available: http://puslit2.petra.ac.id/ejournal/index.php/stikes/article/view/18838/18533.

[9] Misnadiarly, Osteoartritis : penyakit sendi pada orang dewasa dan anak, faktor risiko, infeksi, pencegahan, dan pengobatan. Jakarta: Pustaka Populer Obor, 2010.

[10] S. Aisyah, "Manajemen Nyeri Pada Lansia Dengan Pendekatan Non Farmakologi," J. Keperawatan Muhammadiyah, vol. 2, no. 1, 2017, doi: 10.30651/jkm.v2i1.1201.

[11] dkk Rudjiman, Buku Acuan Umum Tumbuhan Obat Indonesia Jilid II. Jakarta: PT. Dian Rakyat, 2014.

[12] Saryono and A. DM, Metodelogi Penelitian Kualitatif dan Kuantitatif dalam Bidang Kesehatan. Yogyakarta: Nuha Medika, 2013.

[13] Sugiyono, Metode Penelitian Kuantitatif Kualitatif dan $R \& D$. Bandung: Alfabeta, 2011.

[14] S. Notoatmodjo, Metodologi penelitian kesehatan. Jakarta: Rineka Cipta, 2010.

[15] A. Emmanuel, G. Achema, S. Gimba, M. Mafuyai, B. Afoi, and I. . Ifere, "Dysmenorrhoea: Pain relief strategies among a cohort of undergraduates in Nigeria," Int. J. Med. Biomed. Res., vol. 2, no. 2, pp. 142-146, 2013, doi: 10.14194/ijmbr.227.

[16] S. C. Smeltzer and B. G. Bare, Buku ajar keperawatan medikal-bedah Brunner \& Suddarth, 8th ed. Jakarta: EGC, 2013.

[17] S. Andarmoyo, "Buku_Konsep dan Proses Keperawatan Nyeri." Ar-Ruzz, Yogyakarta, 2013.

[18] R. G. Brito et al., "Citronellol, a monoterpene alcohol, reduces nociceptive and inflammatory activities in rodents," J. Nat. Med., vol. 66, no. 4, pp. 637-644, 2012, doi: $10.1007 / \mathrm{s} 11418-012-0632-4$.

[19] M. Sarah, "Pengaruh Kompres Serei Hangat Terhadap Intensitas Nyeri Artritis Rheumatoid Pada Lanjut Usia Di Panti Jompo Graha Residen Senior Karya Kasih Medan," J. Mutiara Ners, pp. 238-243, 2017.

[20] C. S. Chilappa, W. S. Aronow, D. Shapiro, K. Sperber, U. Patel, and J. Y. Ash, "Gout and hyperuricemia.," Compr. Ther., vol. 36, pp. 3-13, 2010, doi: 10.1136/ard.36.5.487b. 